\title{
Review
}

Author(s): E. A. R.

Review by: E. A. R.

Source: The Geographical Journal, Vol. 59, No. 3 (Mar., 1922), pp. 211-212

Published by: geographicalj

Stable URL: http://www.jstor.org/stable/1781768

Accessed: 26-06-2016 15:52 UTC

Your use of the JSTOR archive indicates your acceptance of the Terms \& Conditions of Use, available at

http://about.jstor.org/terms

JSTOR is a not-for-profit service that helps scholars, researchers, and students discover, use, and build upon a wide range of content in a trusted digital archive. We use information technology and tools to increase productivity and facilitate new forms of scholarship. For more information about JSTOR, please contact support@jstor.org.

The Royal Geographical Society (with the Institute of British Geographers), Wiley are collaborating with JSTOR to digitize, preserve and extend access to The Geographical Journal 
general reader as well as the student, which justifies the inclusion of some matter not strictly geographical. There is a great deal of useful statistical matter. The illustrations are both numerous and well chosen, and there are several coloured maps. We hope that the number of volumes in this series will grow rapidly.

R. N. R. B.

\section{POLAR REGIONS}

South with Scott.- Captain E. R. G. R. Evans, C.B., R.N. London and Glasgow: Collins. 1921. Frontispiece and Maps. Ios. 6d. net.

Captain Evans says in his Preface that "The object of this book is to keep alive the interest of the English-speaking people in the story of Scott and his little band of sailor adventurers. It is written more particularly for Britain's younger generations." If only on that account the book deserves to be widely read; it is written in a simple yet interesting way, with occasional exciting interludes. Especially good are the accounts of the winter journey to Cape Crozier, of how Crean and Lashly took charge when the author fell a victim to scurvy (pp. 223-225), and of how the Northern Party lived through a winter on little food but a keen sense of humour. A good deal of important new matter is also to be found scattered through the pages of the book-a full account of the beginnings of the Expedition, Scott's carefully thought-out and lucid instructions to his subordinates, and finally quotations from Bowers' diary. It should appeal therefore to the small public interested in all polar work, and can be thoroughly recommended as a useful addition to Antarctic literature. There are some sledging hints, the outcome of the author's own experiences. He might perhaps have said more about the difficulties of snow at very low temperatures ; this was one of the reasons put forward for Scott's breakdown, but is it well substantiated?

In more than one place Captain Evans pays a fine tribute to the ability and energy shown by Dr. Atkinson, who became leader of the Shore Party on account of Evans' compulsory return to New Zealand. This is worth noting by reason of attempts made recently in some quarters to disparage the author. It is surely common knowledge that, following. Scott's death, Evans as second in command became head of the expedition, but was unable owing to ill health to assume the duties of leader on the spot till the Terra Nova returned after the second winter to bring back Campbell and Atkinson's parties. There is nothing in the present narrative indicating a desire for more credit than is properly due ; one even regrets that the author has succeeded only too well in almost entirely suppressing his own personality. The book runs to 284 pages ; the moderate price is due to there being no illustrations, with the exception of the frontispiece and three useful maps.

J. M. W.

\section{MATHEMATICAL AND PHYSICAL GEOGRAPHY}

Factors for Converting Rectangular to Geodetic Co-ordinates between parallels $4^{\circ}$ and $60^{\circ}$. Computed by C. E. Tildesley, A.C.G.I., A.M.Inst.C.E., B.C.L.S. British Columbia : Department of Lands.

Relation between Plane Rectangular Co-ordinates and Geographic Positions. Walter F. Reynolds, Chief Geodetic Computor, U.S. Coast and Geodetic Survey. Washington, D.C., 1921. Special Publication No. 7r. Price 10 cents.

Any means of shortening the computation work of the surveyor is to be commended provided there is not loss of accuracy in the result, and with that 
object in view the above sets of tables for converting rectangular to geodetic co-ordinates, and vice versâ, have recently been prepared for the use of Government surveyors in British Columbia and the United States.

Last year Mr. Tildesley forwarded to the Society a small set of tables which he had computed for use in British Columbia, giving factors for every to minutes of latitude between the parallels of $42^{\circ}$ and $60^{\circ}$, and he has now brought out a more complete and extended set, with additional tables, giving the logarithmic factors to seven and four figures for every minute of latitude from $48^{\circ}$ to $60^{\circ}$. These limits include the whole of British Columbia, where they are specially intended for use ; but of course they could be used equally well in any part of the world within these limits of latitude.

Mr. W. F. Reynolds, of the U.S. Coast and Geodetic Survey, has recently brought out a set of tables for the same purpose as Mr. Tildesley's for the United States, extending from the 24 th to the 49 th parallel, and giving valucs for every Io seconds of latitude, together with the logarithmic factors to seven and five figures. The two sets supplement each other, and should be very useful in shortening the computations of the surveyor. Although the arrangement and method of computation is somewhat different, both Mr. Tildesley's and Mr. Reynolds' tables are arrived at by rearranging the lengthy fundamental formulæ and combining certain quantities so as to form constant logarithmic factors for the various latitudes. Where the latitudes overlap it is possible to compare results, and it will be seen that in the last figures of the logarithms there are at times considerable differences. Mr. Tildesley has based his tables on Clarke's 1866 figure, while Mr. Reynolds states that he has in his computations referred to Hosmer's Geodesy, where the tables are also from Clarke's 1866 figure, and to tables in manuscript form by Mr. L. A. Chase.

Mr. Tildesley's latest tables are not yet in print, but are photographic reproductions of the manuscript ; but it is hoped that they will be published before long in pamphlet form by the Department of Lands of British Columbia.

$$
\text { E. A. R. }
$$

\section{GENERAL}

Nile and Jordan: an Archæological History of the Inter-relations between Egypt and Palestine, from the earliest times to the Fall of Jerusalem in

A.D. 70.- G. A. Frank Knight, M.A., F.R.S.E. London: James Clarke \& Co. 1921. 8vo. Pp. xii. 572. With five Maps. 36s. net.

The author's object is "to trace the various links which united these continuous territories," Egypt and Palestine. He has searched for them in more than 1700 volumes and journals, of which an alphabetical list is given in an appendix. His perspective in time is explained in another appendix: from Solomon's Temple he reckons back to Abraham's birth, allowing 175 years for his lifetime, I80 for that of Isaac, and IIo for that of Joseph. Biologists will form their own opinion of these estimates. The birth of Moses in 1525 B.c. "exactly harmonizes with the period when Hatshepsut was a princess but not yet full queen of Egypt" (p. 517); so it must have taken a long time. Geographically, Dr. Frank Knight is concerned to show "how misleading such a conception is" as that "Egypt is an integral part of Africa, and Canaan as unquestionably belongs to Asia" (p. I). Analysis of the species of fishes, for example, from the Lake of Tiberias and the Jordanic basin " points, not to any affinity with the fauna of the Orontes or of the Euphrates, but to that of Tanganyika and the other great African lakes." Josephus made a similar observation; but a good deal has happened to qualify conclusions from 